\title{
The Role of Community Organizations in the Transformation of the Social Development Model in Québec ${ }^{1}$
}

\author{
Christian Jetté
}

Université de Montréal

\begin{abstract}
Community organizations have played a major role in the delivery of social services in Québec since the 1970s. Their activities aimed to provide an alternative to the heteronomous, bureaucratic practices of the public sector. But their desire to move away from the public sector did not prevent them from demanding financial support from the state. Historically, these associations' struggles have led to the establishment of an original partnership and a funding mode whereby they could retain their organizations' autonomy. This autonomy was the guarantee of both their specificity and their ability to innovate in terms of social practices. While this state recognition certainly remains in some respects ambivalent, it is nonetheless undeniable that these associations today constitute a significant component of the Québec model of social development.
\end{abstract}

\section{RÉSUMÉ}

Les organismes communautaires jouent un rôle important dans la prestation de services sociaux au Québec depuis les années 1970. Leurs activités se sont développées dans l'optique d'apporter une alternative aux pratiques hétéronomes et bureaucratiques du secteur public. Cette volonté de se distancier du secteur public ne les a toutefois pas empêchés de revendiquer le soutien financier de l'État. Historiquement, les luttes menées par ces associations se sont donc traduites par la mise en place d'un partenariat original et l'établissement d'une mode de financement qui leur permet de préserver l'autonomie de leur organisation. Cette autonomie est le gage de leur spécificité et de leur capacité d'innover sur le plan des pratiques sociales. Certes, cette reconnaissance étatique demeure à certains égards ambiguë. Néanmoins, il est indéniable que ces associations constituent aujourd'hui un élément important du modèle québécois du développement social.

\section{Keywords / Mots clés}

Community organizations; state; social development model; innovation; funding / Organismes communautaires; État; Modèle de développement social; Innovation; Financement 


\section{INTRODUCTION}

The action of community organizations has proven pivotal in the past three decades in the evolution of the social development model in Québec. Seen at the outset as providers of residual services operating on the fringe of the system, community organizations gradually gained legitimacy during the 1980s and 1990s in the context of frequently innovative social practices that offered solutions to the shortcomings of the bureaucratic state. It is estimated that in 2009-2010 the sums invested in community organizations by the Québec government provided full-time work for the equivalent of more than 30,000 people in Québec, and ensured the participation of many thousands of volunteers. Moreover, that same year, the Québec government paid almost $\$ 844$ million to more than 5,000 comunity organizations (SACAIS, 2010). This is clear evidence of the community sector's activities being recognized, despite the ambiguities and sociopolitical tensions that accompanied this financial support.

Our aim in this article is to analyze the role that community organizations played in the evolution of Québec's social development model. To do so, we first look back at some of the main innovations put forward by the community sector in the health and social services system in Québec. Second, we will show that community groups' influence is, however, neither the sole nor even the most telling influence to have had an impact on the system's transformation. A number of management principles, with their origins in the market sector, significantly affected the general alignment of services.

The influence of community groups has grown since the early 2000s, and this has affected the institutional framework benchmarking community organizations' participation in the delivery of health and social services. This will lead us, thirdly, to demonstrate that although the principles associated with new public management (NPM) reflected the government's growing concern with the efficiency and effectiveness of the system, their rigid, authoritarian application prompted a re-evaluation of the institutional compromises that led historically to the deployment, within the system, of the social innovations generated by community practices. The government thereby weakened one of the fundamental elements of the Québec model of social development. First, though, we will present some of the theory and methodology behind the benchmarks that guided the work for this article.

\section{THEORY AND METHODOLOGY}

To take into account the community sector's decisive impact on the evolution of Québec's social development model, we use a theoretical framework that allowed us to analyze the complex interactions operating within the processes of crafting the institutional and organizational forms that structure society (Touraine, 1973). Our analyses were therefore based on three converging theoretical approaches-social movement theory, regulation theory, and convention theory-whereby social stakeholders (e.g., community organizations, labour unions, public servants) have the capacity to transform social relationships, particularly in their dealings with the government or among groups in society. These three theoretical approaches are complementary since they each address a specific dimension of the topic of our study. 


\section{Jetté (2011)}

However, the theoretical approaches are arranged in such a way that each of their contributions refers to a given level of analysis so that they are not in contradiction with or disconnected from the topic of our study. We use social movement theory to explain social conflicts and social stakeholders' relationships with the processes of production and reproduction of societal institutions (social relationship dimensions) (Neveu, 2002); we use regulation theory for the institutionalized compromises produced by these stakeholders to resolve their conflicts and structure the resulting development models (institutional dimension) (Boyer \& Saillard, 2002); and we use convention theory to identify the forms of criticism and "justification" at work in the coordination of systems and organizations delivering services (organizational dimension) (Boltanski \& Chiapello, 1999).

While social movement theory and regulation theory are relatively well known to researchers as a whole, convention theory - and in particular its variant as formulated by Boltanski, Thévenot, and Chiapello as an "economy of worth" (économie des grandeurs)-is perhaps less familiar. To the best of our knowledge, these authors' work has never been fully translated for an English-speaking readership (Boltanski \& Thévenot, 1991; Boltanski \& Chiapello, 1999).. ${ }^{2}$ That is why we feel it is helpful here to provide some clarification on a number of the concepts developed by these authors.

The "justifications" talked about by Boltanski, Thévenot, and Chiapello are defined on the basis of the principles of action implemented by social stakeholders in a specific situation. They talk, for instance, of the appropriateness of a habit justified by the principle of tradition (domestic worth); the inspiration that led to an original creation or an innovation (inspired worth); the validity of a technical process or the reliability of technological equipment justified by an industrial measurement and evaluation process (industrial worth); and the legitimacy of a decision based on the expression of a collective will through democratic processes (civic worth) (Boltanski \& Thévenot, 1991). These justifications thus refer to a number of "higher principles" that become more prominent at times of conflict or dispute, when these principles and the mechanisms on which the operation and co-ordination of the systems or organizations at issue are based are seen to be challenged. The work of clarifying and ranking the principles begins among the stakeholders concerned, through a process aimed at re-establishing human justice and fairness or the fitness and justness of processes and objects, depending on the situations involved.

We recognize that these statements are rather brief for anyone wishing to grasp the full scope of some of the concepts put forward in this paper. Readers wishing to examine these questions in greater depth are therefore invited to consult the original work that gave rise to the theoretical discussions concerning these approaches (Jetté, 2005a). These remarks also apply to methodological issues. The project from which this article stems involved 40 interviews with key informers from the community sector (heads of province-wide coalitions, leaders of social movements, etc.) and the public sector (provincial and regional officials), as well as the analysis of hundreds of documents generated by stakeholders from the public sector and third sector (Jetté, 2005a).

Before we begin our analysis, some clarification concerning the concept of social innovation is warranted to distinguish it from the concepts of social movement and social change. Social innovation may be seen as a process aimed at "the establishment of new social arrangements, new forms of mobilization of resources and new responses to problems to which the known solutions are inadequate" (Klein, Fontan, Harrisson, \& Lévesque, 2009, p. 3 [unofficial translation]). But social innovation must not be confused with social movement. While social movement is often an "incubator of social innovation," its scope is much broader and deeper, involving collective action aimed at social change at a societal level. In other words, social innovation can lead to social change if it is proposed by social stakeholders who are in a 
position to disseminate it to a large number of organizations and to establish a power relationship sufficient to overcome the barriers put up by social stakeholders who are opposed to it. The social stakeholders propelling the change thereby force the establishment of new compromises that bring a new meaning to social relationships and crystallize the social change (Klein et al., 2009, pp. 4-5).

Community organizations cannot be reduced to a mere subsector of the private sector with non-profit characteristics. Rather, we place them within a third sector alongside the public and private (market) sectors. Like other researchers (Defourny \& Monzon Campos, 1992; Spear, Leonetti, \& Thomas, 1994; Bélanger, 1999; Vaillancourt, 2006), we include non-profit organizations, cooperatives, mutual aid societies, and social economy enterprises in the third sector. Despite the variability in empirical practices observed in the field in Québec ${ }^{3}$ and in Canada in general (Hall et al., 2004), these organizations and enterprises both comprise a grouping of individuals (rather than shareholders) with specific, formal rules that have been democratically adopted, thus enabling them to make tradeoffs between their objectives of economic and social viability (Jetté, Lévesque, Mager, \& Vaillancourt, 2000). They also share the goal of social utility and common interests that excludes seeking profit on the basis of capital-based share ownership (Favreau, 2005). In this respect, community organizations in Québec are "an essential component of this third sector" (Bélanger, 1999), and clearly contribute to the shape of Québec's social development model.

\section{A SOCIAL DEVELOPMENT MODEL FUELLED BY SOCIAL INNOVATIONS ORIGINATING WITH COMMUNITY GROUPS}

Our research has shown that, over the past 30 years, community organizations have constituted a formidable source of social innovation for the ministère de la Santé et des Services sociaux du Québec (MSSS) in terms of practices (organizational dimension) and the nuts and bolts of their relations and interactions with government (institutional dimension) (Jetté, 2005a, 2008). The process of institutionalization whereby the community clinics of the early 1970s were converted into local community service centres called centres locaux de services communautaires (CLSCs) - public establishments combining primary social and health services in one location-proved to be the trigger for a long line of generalization and transfer of practices. Initially tested in the community sector, these included practices concerning abused women, mental health, and young people. Nevertheless, in the context of the period, the institutional conditions for transferring and maintaining these innovations in community clinics (that is, the CLSCs) showed clear limitations. This mode of institutionalization was in fact heavily dependent on the Fordist and welfare state model of development in effect at the time, and on the main institutions that structured the system, including a centralized bureaucracy, a Taylorist division of labour, and standardized programming of services (Jetté, 2005b).

The institutionalization of grassroots groups within the CLSCs was characterized by hierarchical integration and state control, which acted as a structural brake on maintaining the innovations present at the outset in those organizations. The forms of coordination required by the practices of community groups (e.g., militancy, participation, and experimentation) were not very compatible with those of the public sector (e.g., control, rationalization, and standardization). The initial compromise that the reformers of the health and social services system attempted to impose at the time between social and medical practices and the requirements of standardization stemming from the technocratic organization of public services, and the autonomy of associations' practices, could not be maintained over time. This was

ANSERJ To be notified about new ANSERJ articles. click subscribe. 
attributable in particular to the low level of political and symbolic recognition enjoyed by community organizations compared with that of the medical world and the public sector, including the labour unions. But this partial failure-partial because the CLSCs were nevertheless a success on other fronts-would not put an end to the dynamics of recognition, transfer, and generalization of community practices.

\section{Community-centred change}

In this regard, the practices developed by women's groups with respect to violence would in turn become standard practice and be partially transferred to the public sector in the mid-1980s. But this time the organizational innovation would lead to experimentation at the institutional level; that is, innovation would occur in the actual process of transferring innovation. Thus, women's groups saw their practices receive province-wide recognition within the framework of the policy on abused women adopted in 1985 (MAS, 1985), but without any state control of their organization, as had happened with community clinics during the previous decade (Bélanger, Lévesque, \& Plamondon, 1987). Rather than these resources being integrated into the public sector, their autonomy was preserved at the same time that they were awarded funding which, although certainly still contingent on the ministry's available budgets, nonetheless proved sufficient to ensure their development in subsequent years. This phenomenon was to be repeated later, under specific terms and conditions, within other components of the community sector, notably certain organizations working with young people (youth homes) and alternative mental health organizations (RMJQ, 1996; MSSS, 1989).

As to the actual process of disseminating innovation, its characteristics were largely crystallized around the community organization support program (SOC), a program set up in 1973 to fund community organizations on the basis of their general mission, and permitting minimal reporting geared to the organizations' operating methods (MSSS, 2008). Once the partial failure of the process of institutionalizing community clinics was accepted by the Québec government in the 1980s, they resorted to other forms of arrangements to maintain and perpetuate the innovations initially present in community organizations.

Contrary to the strategy of state control used in the early 1970s, and under pressure from social movements, Québec's social affairs ministry, the ministère des Affaires sociales (MAS), gradually became aware of the specific nature of community organizations, the close relations they maintained with local communities, and the specific mindsets that characterized them (militancy, participation, reciprocity, and experimentation). This change in perspective with respect to community organizations was also fuelled by certain stakeholders within Québec's civil service, particularly the Council on Social Affairs and the Family (Conseil des affaires sociales et de la famille, CASF). The CASF had a mandate to advise and inform the ministry on the best strategies to be adopted with regard to health and social services. During the second half of the 1970s this advisory council published two position papers strongly emphasizing the need to preserve these principles of participation and reciprocity if the government wished to maintain an environment conducive to the emergence of innovation and experimentation within the community sector (CASF, 1976, 1978). The result was that, from the 1980s, when the future of the welfare state was being questioned, the Québec government was more open to the development and funding of a community or third sector, comprising non-profit organizations, to assist it in its health and social services mission. 


\section{Community sector recognition and transformation}

The increased recognition of community organizations prompted certain elements in the Ministry of Health and Social Services to propose new institutional arrangements that would help protect the community sector from being excessively subjected to the priorities and constraints of the public sector, so as to preserve their capacity for social innovation. This realization partly originated in budgetary constraints and the economic downturn following the first signs of exhaustion of the welfare state model in the late 1970s. But it also arose from awareness work carried out by public servants within the ministry itself, primarily those working in the community organization support service, the Service de soutien aux organismes communautaires (SSOC), the administrative unit in charge of managing the SOC program. For these officials, who had the opportunity of expressing their views at the Rochon Commission hearings in 1986, ${ }^{4}$ the community sector represented more than mere cut-rate subcontractors providing services not delivered by the public sector; it constituted new service deliverers with their own specific features that made it possible to integrate principles of action (i.e., reciprocity, participation, and experimentation) that had largely been eliminated from the health and social services system by the bureaucratic, technocratic organization of the public sector. In other words, the contribution of community organizations allowed the MSSS not only to inject new resources at low cost into the system, but above all to make a qualitative leap forward in the delivery of services to the public (SSOC, 1986).

This evolution in the relationships between the public sector and the third sector would pass a significant milestone and, finally, lead to a new compromise in 1990 upon the application of a major health and social services reform: the Côté reform 5 (Jetté, Lévesque, \& Vaillancourt, 2001). This entailed regionalization and some democratization in the organization of health and social services, particularly the creation of regional boards (régies régionales) and the introduction of elected positions on the boards of directors. These new establishments had a mission to plan, organize, and deliver health and social services within their geographical areas. The community sector's contribution to the health and social service system would then be the subject of a large-scale process of institutionalization, within the framework of certain sections of the new law structuring this reform. This was accomplished through the establishment of specific terms and conditions for funding stemming from the SOC program. These arrangements then converged to model a new approach to the contribution of community organizations within the health and social services system: regionalization of budgets, maintenance of the organizations' autonomy despite the provision of public funding, funding for their overall mission, minimum accountability, and participation in regional decision-making bodies (MSSS, 1990). This new model reflected the principles of what Boltanski and Chiapello call the critique artiste, a form of criticism using principles of autonomy and innovation to remodel institutions and organizations (Boltanski \& Chiapello, 1999).

From the 1990s there thus began a transformation of the social development model in Québec. The model of the centralized welfare state delivery of services retreated, making room for an approach that was more plural, in terms both of service deliverers and of mindsets at work within the health and social services system. At the theoretical level, these new approaches were given various names, depending on the orientation and goals targeted by these transformations: "partner state" (État accompagnateur), "entrepreneur state," "facilitator state," "Schumpeterian state," "social investment state," and "strategist state" (État stratège) (Saint-Martin, 2007; Côté, Lévesque, \& Morneau, 2009; Noël, 1996; Jessop, 1993; Barreau, 1990). More recently, the more generic concept of the "social state" appeared (or reappeared). This goes beyond the concept of welfare state in that it encompasses a new configuration for taking charge of social issues (Merrien, Parchet, \& Kernen, 2005). Generally speaking, these approaches

ANSERJ To be notified about new ANSERJ articles. click subscribe. 
highlight the fact that the welfare state model was outdated and outflanked by pluralistic public policy, where one sector alone-public, private, or third sector-could not dominate the delivery of public services (Abrahamson, 1999; Boyer, 2006; Donzelot, 2007).

\section{INFLUENCE OF NEW PUBLIC MANAGEMENT ON THE ORGANIZATION OF HEALTH AND SOCIAL SERVICES}

The Québec state did not evolve in a vacuum. It was also shaped by market forces during the 1980s and 1990s, even if those influences were not felt as intensely as in some other Canadian provinces or the United States (at least, until the early 2000s) (Vaillancourt \& Tremblay, 2002). Some of the political players-first among them Robert Bourassa's Liberal Party, in power from 1985 to 1994-flirted with the idea of a more marked application of the market, neoliberal orientation to the health and social services system. This neoliberalism manifested itself in the privatization of certain establishments, and the imposition of co-insurance (ticket modérateur) and income tax on services (impôt-service).

The Liberal government set up a task force, the Groupe de travail sur la révision des fonctions et des organisations gouvernementales, in 1985, and its report on the role of government advocated abolishing a whole series of advisory bodies, privatization of certain hospitals, dismantling of certain regional authorities, complete decentralization of the management of establishments, and widespread use of subcontracting as a service delivery mode (Gobeil, 1986). Bourassa's government finally retreated in the face of the uproar provoked by some of the proposals in this report, and by some of the more controversial sections of the draft legislation piloted by Marc-Yvan Côté (MSSS, 1990). Political pressure (both from the public and from social movements), and the penalties associated with potential violations of the Canada Health Act, finally won out over the neoliberal inclinations of the provincial government. The privatization movement was thus curtailed in very specific areas, such as housing for the elderly, home services, and auxiliary services in hospitals (Vaillancourt \& Jetté, 1997).

\section{Reform by stealth}

The penetration of the market mindset in Québec took place more subtly and less spectacularly than privatization or imposition of direct user fees would have done. Instead, the values and principles of the market sector were introduced through forms of management and the question of system effectiveness. In this regard, the early 2000s were a turning point, primarily following the publication and implementation of certain recommendations of the report produced by the Clair Commission (Commission d'étude sur les services de santé et les services sociaux) (Clair, 2000). The Québec government was forced to alter its strategy and policy to counter constantly rising health care costs. Public health and social services establishments then became the target of management principles inspired by the private sector, namely New Public Management (NPM). This growing influence of management sciences on the management of services would thus toll the death knell for the experiment with the regionalization and democratization of the health and social services system that had begun in 1991.

It was therefore largely in an attempt to regain control over the hospitals' financial situation that governments, both Parti Québécois and Liberal, put an end to the experiment with regionalization and democratization of the system in the late 1990s. Notwithstanding the advantages brought by this regionalization, such as resources for primary care services delivered by the CLSCs and community organizations, the hospitals' inability to stay within budget led successive governments to realign the system to take back control of health care spending.

ANSERJ To be notified about new ANSERJ articles. click subscribe. 
The imposition of more authoritarian, hierarchical governance reflects the predominant influence of health care circles over social services within the health and social services system. It also reflects a dual orientation within the system, and a real paradox in government action since the late 1990s. In 2001, the government introduced a Policy on the Recognition and Support of Community Action inspired by the SOC program (SACA, 2001). This policy benchmarked the overall relationships of Québec government ministries with the community sector, favouring funding for the latter aimed at supporting their general mission. In 2004, the MSSS published a framework and a government action plan on community action which, while limiting the growth of financial resources granted to community organizations, also renewed the government's recognition and autonomy of community organizations (MSSS, 2004a, 2004b).

At the same time the government initiated another reform (the Couillard Reform) ${ }^{6}$ imbued with ambiguities as to the future relationship between community organizations and health and social services centres (CSSSs). CSSSs were new local bodies born out of the merger of CLSCs, hospitals, and longterm residential care centres within a geographical area. The CSSSs' mission was to coordinate that area's overall health and social services, whether public, private, or community-based. This reform was directly descended from the principles of New Public Management (NPM). In NPM managerial practices from the market sector are promoted, together with the attainment of results by building on the accountability of the stakeholders involved in the delivery of services, and the implementation of performance incentives (Amar \& Berthier, 2007).

In health and social services, the application of the principles of NPM translated into a reinforcement of political authority to the detriment of the power of regional administrations and community organizations over the orientation of services (Larivière, 2005). The conversion of regional boards into health and social services agencies in 2001 and the reform of their boards of directors on the basis of co-opting directors with management expertise was the first stage toward a "measurable" approach to the system's results and performances (MSSS, 2004c). This NPM orientation effectively negated the power that community organizations had worked to develop regionally since 1991.

\section{Devolution to community}

The creation of the health and social services centres (CSSS) in 2003 constituted the second stage in these changes, which displaced the system's centre of gravity from the regional to the local level. But this displacement appears to correspond more to a devolution operation than to a true process of decentralization. Under this new structure, major policy positions and the determination of budget priorities fell to the central authority (the ministry), while the administrative stakeholders (CSSSs) were used to achieve budget tradeoffs at the local level. The MSSS favoured service agreements between these new CSSSs and service deliverers from the third sector (community organizations and social economy enterprises) as well as the private sector (particularly private residential facilities for the elderly). These new agreements were viewed by the ministry as a way to ensure the integration of services while keeping them within a defined financial framework. But this type of arrangement violated the basic principles of the relationships that had developed historically between the MSSS and the community sector, in particular through the Community Social Support program. Service agreements in this context were defined more as subcontracting operations supervised by a government unilaterally determining the conditions of the supply of services (Bourque, 2005). 


\section{Implications for community organizations}

New issues arose for community organizations, such as having to defend funding for the overall mission awarded through the Community Social Support program, while applying the industrial principles of efficiency and effectiveness. The history of the development of the community sector shows that the organizations' autonomy is above all based on their ability to carry out the majority of their activities outside the financial constraints associated with attaining performance goals. Performance goals and evaluation tools are not compatible with achieving their mission. The achievement of their mission and the specificity of their practices lie in their ability to mobilize principles of action that are harder to objectivize. These principles play a crucial role in the delivery of services to individuals, namely citizen participation, reciprocity and giving, innovation and experimentation, creation of social linkages, and proximity to users. Paradoxically, maintaining these principles of action proved to be the condition, as noted above, for the optimization of their performance with respect to communities' health and welfare.

Seen in the light of industrial instrumentality, community organizations operate under a significant amount of uncertainty: uncertainty as to the cost of services ( e.g., funding for the overall mission including a broad spectrum of action over which the directors have little control); uncertainty as to the time required for the action (difficulty measuring the time needed for mobilization and empowerment of communities); and uncertainty concerning the determination of the short-, medium-, and long-term effects of the action (e.g., effects that are often preventive, lending themselves less immediately to standard evaluation processes) (Le Bossé \& Dufort, 2001, pp. 96-104). Uncertainty too because community groups operate in the field of social services, where the grip of the accounting mechanisms of NPM are weaker. ${ }^{7}$ And finally, uncertainty in terms of epistemology, as their action can sometimes run counter to the know-how and measures advocated by managerial experts. Such expertise in managerial know-how, substantially mobilized by NPM, also legitimizes the increased use of actions built on the evidence-based model. This evidence-based model postulates that by implementing practices that have been verified empirically (evidence-based measurement), these practices will become effective and will lead to better cost control (Lecomte, 2003). Managerial practices and epidemiological practices are thus combined here, through a common philosophy of instrumental rationality, to reinforce the mindset of industrial production in the health and social services field.

\section{NEW COMPROMISES TO BE FORGED}

Community organizations nevertheless enjoy certain advantages in this situation, which at first glance may seem unfavourable. Their increased presence gives them a political clout that they lacked during the 1970s and 1980s, but more than that, the compromise that these organizations managed to establish between certain traditional demands of the Left (such as social justice, economic security, and equality among citizens) and principles originating in the cultural revolution of the 1970s (individual and community autonomy, innovation in intervention practices, and healthier lifestyle and environmental practices) constituted an innovative alternative to both the traditional welfare state and neoliberalism. Community organizations' action led to the introduction of a true welfare pluralism not limited to the private and public sectors, but built on modes of exchange and delivery of services emerging from the dynamics of reciprocity (Evers \& Laville, 2004).

Furthermore, in the context of uncertainty generated by the adoption of new management modes, the existence of negotiated agreements, recognized through certain legislation and social policy, becomes a considerable asset, enabling community organizations to preserve their gains and continue to exert some

ANSERJ To be notified about new ANSERJ articles. click subscribe. 


\section{Jetté (2011)}

influence on the health and social services system. In this regard, funding of the overall mission received by community organizations in the health and social services field in Québec through the SOC program, and subsequently broadened to all community groups in 2001 through the policy of the secretariat for autonomous community action, the (SACA) (SACA, 2001), is a fine example of an agreement that successfully reconciles the the community sector's principles of participation, innovation, and reciprocity with the principles of accountability, effectiveness, measurement, and budget control applied by the government. This is despite the fact that recent research shows that the SACA's policy has been implemented very unevenly by different ministries and there is a long way to go before Québec's entire community sector enjoys full recognition and adequate funding (White, 2008).

The recognition acquired by community organizations in Québec thus stems not only from the efforts made to find solutions to the welfare state crisis, but also from the unceasing struggle of the community sector, which has forced the government to negotiate a new type of compromise between policies that until then had often proven irreconcilable. The development of this type of arrangement is crucial, because it could well constitute, in certain conditions, an alternative to the privatization of public services. Wedged between the defenders of the traditional welfare state model and the supporters of the market orientation, the community sector has every interest in gaining recognition for the specificity of its relations with the government in areas of public interest. The non-profit character of the organizations delivering services will always remain a strong signal of confidence for vulnerable individuals and communities in need.

\section{CONCLUSION}

Community organizations, as a component of the third sector in the health and social services field, have contributed in a decisive manner to shaping the social development model in Québec. Their impact has been felt in particular through their ability to innovate and engage in political action. These dual actions have been part of the burgeoning of new forms of practice and new social policies, and the establishment of new relations with the government. Community organizations have set themselves up as "co-constructors" of new public policy and promoters of an alternative development model, whose principles have marked the evolution of the welfare state since the 1980s.

This co-construction of new mechanisms, and the recognition of the community sector, occurred because of the establishment of formal and informal alliances with stakeholders operating within the public sector. These supports within the government itself led to institutionalized compromises that benchmarked the terms of community organizations' participation in the delivery of health and social services.

This commitment from public sector stakeholders toward the community sector has varied, depending on the period and the identity of those in certain key positions within government and the public service. But the growing establishment, particularly since the late 1990s, of managerial mechanisms borrowed from the market sector clearly illustrates the limits of this support. This circumstantial solidarity between the community sector and certain public sector stakeholders never really led to the reversal of the major neoliberal trends at work within the system. As a result, the fragile balance of the compromises forged over the past 30 years is sometimes jeopardized.

The government's obsession with budget controls and instrumental measurement tends to reduce the formal spaces for participation and dialogue (and thus the political space) necessary for the consistent 


\section{Jetté (2011)}

expression of principles of action advocated by community organizations. Thus, policy decisions are made as if the government had embarked on a new form of managerial rationalization solely to resolve the problems generated by a certain bureaucratic streamlining of services and certain rigidities in the system. This increases the presence of instrumental measures within the system, and moves issues toward the attainment of goals determined within technocratic bodies. In this context the establishment of a consensus around this new issue should, according to the artisans of these new reforms, remove the obstructions behind the system's dysfunction. But the establishment of a new organizational framework for action focusing on the integration of resources on its own cannot resolve an issue, some elements of which are of a political nature, particularly when this framework has been in place since the early 2000 s.

It is the desire to achieve a common good that needs to motivate the effective adaptation to the demand for services, not the maximization of the performance of human, physical, and financial resources. The tangible achievement of the common good and general interest requires a political process that remains demanding even with outcomes that remain uncertain. Such a process would lead to a new balance of power between populations and service deliverers, and among service deliverers themselves, along the lines of what had been initiated in the early 1990s with the regionalization of services. In light of our research findings, it is our view that only by submitting to these democratic requirements will it be possible to move the system forward toward genuine welfare pluralism, and circumvent obstructions induced by the corporatist pressures and an instrumental vision of the development of health and social services.

\section{ACKNOWLEDGEMENTS}

I would like to thank the reviewers for the very relevant comments they made on the earlier draft of this article and which helped to improve the quality of the argument. I would also like to thank David Llewellyn for translating the original text from French to English. Finally, I would like to thank the journal editors for undertaking the final proofreading of the manuscript.

\section{NOTES}

1. This paper evolved from a doctoral thesis in sociology successfully defended in 2005 at the Université du Québec à Montréal (Jetté, 2005a). Subsequent research was funded by the Fonds québécois de la recherche sur la société et la culture (FQRSC).

2. Boltanski and Thévenot's book published in 1991 appeared in English translation in 2006 (Boltanski \& Thévenot, 2006).

3. To find out more about this topic, the reader may consult the long list of monographs on third sector enterprises produced by the Laboratoire de recherche sur les pratiques et les politiques sociales (LAREPPS) and the Centre de recherche sur les innovations sociales (CRISES): www.larepps.uqam.ca and www.crises.uqam.ca.

4. The goal of this commission of inquiry into health and social services, chaired by Jean Rochon, was to evaluate the operation and funding of the health care system and make recommendations to the Quebec government. Jean Rochon was Quebec's minister of Health and Social Services from 1994 to 1998.

5. Named after the minister who piloted this reform, Marc-Yvan Côté. Many of the terms and conditions of this reform were inspired by the recommendations of the Rochon Commission report (Rochon, 1988). 


\section{Jetté (2011)}

6. Once again, named after the incumbent minister when the reform was implemented, Philippe Couillard.

7. As the managers of the health and social services centres (CSSSs) would be assessed on the basis of results achieved, one might think it would be in their interest to build on what is measurable and countable. In that regard, the application of instrumental measurements lends itself more easily to the health than the social dimension of services: number of operations, cost of operations, planning of mobilized resources, for example.

\section{REFERENCES}

Abrahamson, Peter. (1999). Le modèle scandinave de protection sociale (The Scandinavian Model of Welfare). In Peter Abrahamson, Didier Blanchet, Aksel Hatland, Nadine Lefaucheur, Joakim Palme, \& Hannu Uusitalo (Eds.), Comparer les systèmes de protection sociale en Europe du Nord et en France (Comparing social welfare systems in Nordic Europe and France), 4(1), pp. 31-62. Paris: MIRE-DREES.

Amar, Anne, \& Ludovic, Berthier. (2007, December). Le nouveau management public : Avantages et limites (The new public management: Advantages and limits). Revue du RECEMAP. URL: www.unice.fr/recemap .

Barreau, Jocelyne. (1990). L'État entrepreneur. Paris: L'Harmattan.

Bélanger, Jean-Pierre. (1999). Les organismes communautaires, une composante essentielle de ce tiers secteur. Nouvelles pratiques sociales, 12(2), December, 89-102.

Bélanger, Paul R., Lévesque, Benoît, \& Plamondon, Marc. (1987). Flexibilité du travail et demande sociale dans les CLSC, Appendix to the Report of the Rochon Commission. Québec: Les Publications du Québec.

Boltanski, Luc, \& Chiapello, Eve. (1999). Le nouvel esprit du capitalisme. Éditions Gallimard.

Boltanski, Luc, \& Thévenot, Laurent. (1991). De la justification. Les économies de la grandeur. Paris: Éditions Gallimard.

Boltanski, Luc, \& Thévenot, Laurent. (2006). On justification: Economies of worth. NJ: Princeton University Press (translation of Boltanski \& Thévenot, 1991).

Bourque, Denis. (2005). Interfaces entre les organismes communautaires et le réseau public: continuité et rupture. Économie et Solidarités, 36(2), 13-29.

Boyer, Robert. (2006). L'hétérogénéité des relations salariales contemporaines et ses conséquences. In Michel Wieviorka (Ed.), Les sciences sociales en mutation (pp. 465-476). Paris: Sciences humaines.

Boyer, Robert, \& Saillard, Yves. (2002). Théorie de la régulation: l'état des savoirs. Paris: La Découverte.

Clair, Michel. (2000). Emerging solutions: Report and recommendations. Commission of study on health and social services (Commission d'étude sur les services de santé et les services sociaux) (Clair Commission). Québec: Gouvernement du Québec.

Conseil des affaires sociales et de la famille (1978). La question de la promotion des initiatives volontaires dans le domaine des affaires sociales au Québec. Québec: Éditeur officiel du Québec.

Conseil des affaires sociales et de la famille (1976). Promotion de la participation des groupes populaires à la gestion des services publics et au développement des communautés. Québec: Éditeur officiel du Québec.

Côté, Louis, Lévesque, Benoît et Morneau, Guy (Eds) (2009). État stratège et participation citoyenne. Québec : Presses de I'Université du Québec.

Defourny, Jacques, \& Monzon Campos, José L. (Eds.). (1992). Économie sociale. Entre économie capitaliste et économie publique/The Third Sector. Cooperative, Mutual and Nonprofit Organizations. Brussels: CIRIEC and De Boeck Université.

Donzelot, Jacques. (2007). Un État qui rend capable. In Serge Paugam (Ed.), Repenser la solidarité. L'apport des sciences sociales (pp. 71-86). Paris: PUF.

Evers, Adalbert, \& Laville, Jean-Louis (Eds.). (2004). The Third Sector in Europe. Cheltenham, U.K., and Northampton, USA: Edward Elgar.

Favreau, Louis. (2005). Qu'est-ce que l'économie sociale? Synthèse introductive. Cahiers du LAREPPS, 5(16), 37. 


\section{Jetté (2011)}

Gobeil, Paul. (1986). Rapports. Report of the Groupe de travail sur la révision des fonctions et des organisations gouvernementales. Québec: Gouvernement du Québec.

Hall, Michael H., et al. (2004). Cornerstones of community: Highlights of the national survey of nonprofit and voluntary organizations. Ottawa: Statistics Canada.

Jessop, Bob. (1993). Towards a Schumpeterian workfare state? Preliminary remarks on post-Fordist political economy, Studies in Political Economy, 40, 7-39.

Jetté, Christian, Lévesque, Benoît, Mager, Lucie, \& Vaillancourt, Yves (2000). Économie sociale et transformation de l'Étatprovidence dans le domaine de la santé et du bien-être. Une recension des écrits (1990-2000). Québec: Presses de l'Université du Québec.

Jetté, Christian (2005a). Le Programme de soutien aux organismes communautaires du ministère de la Santé et des Services sociaux: une forme institutionnelle structurante du modèle québécois de développement social (1971-2001), PhD thesis, Department of Sociology, Université du Québec à Montréal.

Jetté, Christian (2005b). Caractérisation des rapports entre l'État et le tiers secteur associatif au sein du système sociosanitaire québécois: l'émergence de nouveaux modes de coordination. Annals of Public and Cooperative Economics, 76(4), 645-75.

Jetté, Christian. (2008). Les organismes communautaires et la transformation de l'État-providence. Trois décennies de coconstruction des politiques publiques dans le domaine de la santé et des services sociaux. Québec: PUQ.

Jetté, Christian, Lévesque, Benoît, \& Vaillancourt, Yves. (2001). The social economy and the future of health and welfare in Quebec and Canada. Les Cahiers du LAREPPS, 1(4).

Klein, Juan-Luis, Fontan, Jean-Marc, Harrisson, Denis, \& Lévesque, Benoît. (2009). L'innovation sociale au Québec: un système d'innovation fondé sur la concertation. Cahiers du CRISES, ET0907.

Larivière, Claude. (2005). Les risques de la nouvelle gestion publique pour l'intervention sociale. Interaction communautaire, 70, 13-17.

Le Bossé, Yan, \& Francine Dufort. (2001). Le pouvoir d'agir (empowerment) des personnes et des communautés: une autre façon d'intervenir. In Francine Dufort \& Jérôme Guay (Eds.), Agir au coeur des communautés. La psychologie communautaire et le changement social (pp. 75-115). Québec: Les Presses de l'Université Laval.

Lecomte, Yves. (2003). Développer de meilleures pratiques. Santé mentale au Québec, 28(1), 9-36.

Merrien, François-Xavier, Parchet, Raphaël, \& Kernen, Antoine. (2005). L'État social. Une perspective internationale. Paris: Dalloz.

Ministère des affaires sociales. (1985). Une politique d'aide aux femmes violentées. Québec: MAS.

Ministère de la santé et des services sociaux. (1989). Politique de santé mentale. Québec: MSSS.

Ministère de la santé et des services sociaux. (1990). Une réforme axée sur le citoyen. Québec: Gouvernement du Québec.

Ministère de la santé et des services sociaux. (2004a). Plan d'action gouvernemental en matière d'action communautaire. Québec: Gouvernement du Québec.

Ministère de la santé et des services sociaux. (2004b). Cadre de référence en matière d'action communautaire. Québec: Gouvernement du Québec.

Ministère de la santé et des services sociaux. (2004c). L'intégration des services de santé et des services sociaux. Québec: Gouvernement du Québec.

Ministère de la santé et des services sociaux. (2008). La reddition de comptes dans le cadre du soutien à la mission globale. Programme de soutien aux organismes communautaires. Québec: Gouvernement du Québec.

Neveu, Erik. (2002). Sociologie des mouvements sociaux. Paris: Éditions La Découverte.

Noël, Alain (1996). Vers un nouvel État-providence? Enjeux démocratiques, 15 (30) 3-27.

Rochon, Jean. (1988). Report of the Commission of Inquiry on Health and Social Services. Québec: Gouvernement du Québec. 


\section{Jetté (2011)}

Saint-Martin, Denis. (2007). From the welfare state to the social investment state: A new paradigm for Canadian social policy?. In Michael Orsini \& Miriam Smith (Eds.), Critical Policy Studies (pp. 279-299). Vancouver, BC: University of British Columbia Press.

Secrétariat à l'action communautaire autonome (SACA). (2001). Community action: A crucial contribution to the exercise of citizenship and the social development of Quebec. Québec: Ministère de l'Emploi et de la Solidarité sociale, Gouvernement du Quebec.

Secrétariat à l'action communautaire autonome et aux initiatives sociales (SACAIS). (2010). État de la situation de l'intervention gouvernementale en matière d'action communautaire. Édition 2009-2010. Québec: Ministère de l'Emploi et de la Solidarité sociale, Gouvernement du Quebec.

Service de soutien aux organismes communautaires (SSOC). (1986). Les organismes communautaires. Réflexion sur les enjeux actuels et à venir. Brief submitted to the Rochon Commission.

Spear, Roger, Leonetti, Aude, \& Thomas, Alan. (1994). Third Sector Care. Milton Keynes, U.K.: Open University, Cooperatives Research Unit.

Touraine, Alain. (1973). Production de la société. Paris: Seuil.

Vaillancourt, Yves. (2006). Le tiers secteur au Canada, un lieu de rencontre entre la tradition américaine et la tradition européenne. Canadian Review of Social Policy/Revue canadienne de politiques sociales, 56, 23-39.

Vaillancourt, Yves, and Christian Jetté. (1997). Vers un nouveau partage des responsabilités dans les services sociaux et de santé. Cahier du LAREPPS, 97(5).

Vaillancourt, Yves, \& Tremblay, Louise. (2002). Social economy: Health and welfare in four Canadian provinces. Halifax and Montreal: Fernwood Publishing and LAREPPS.

White, Deena (2008). La gouvernance intersectorielle à l'épreuve : Évaluation de la mise en œuvre et des premières retombées de la Politique de reconnaissance et de soutien de l'action communautaire. Rapport final. Montréal : CPDS, Université de Montréal.

\section{About the author / L'auteur}

Christian Jetté is Scientific Co-director for the Laboratoire de recherche sur les pratiques et les politiques sociales LAREPPS, Université de Montréal. Email: christian.jette@umontreal.ca 